\title{
Untreated Childhood Myeloid Neoplasm
}

National Cancer Institute

\section{Source}

National Cancer Institute. Untreated Childhood Myeloid Neoplasm. NCI Thesaurus. Code C115915.

A finding of myeloid neoplasm in childhood that has not been treated. 